\title{
DEVELOPING ENGLISH LEARNING MATERIALS FOR YOUNG LEARNERS BASED ON NEEDS ANALYSIS AT MTSN MODEL MAKASSAR
}

\author{
Miftahul Khair Nur Ali Mubar \\ English Education Department of UIN Alauddin Makassar \\ miftabulkhairnam@gmail.com
}

\begin{abstract}
The main objective of this study was to develop English speaking materials especially speaking as additional learning sources. This research was conducted at MTsN Model Makassar in academic year 2014/2015. In this research, the population was the third grade students. There were 20 students as the respondents of 19 questionnaire questions. The design used by researcher in this research was Research and Development (R\&D). R\&D is a name of one research designs involving the classroom problems, studying recent theories of educational product development, developing the educational products, validating the product to experts, and field testing the product (Latif, 2012). The researcher adopted ADDIE Model. ADDIE is acronym of Analysis, Design, Development, Implementation, and Evaluation.The result of the research showed that, the third grade students of MTsN Model Makassar want English materials especially speaking materials based on their needs. The existing materials that they used in learning still have many weaknesses. Then, these findings become the basic for the researcher to develop English learning materials especially for speaking.Finally, The English learning materials for students called speaking materials consist of six rules as main topic and 18 activities to improve students' speaking ability. The materials presented in 24 pages.
\end{abstract}

KEY WORDS: Developing English Materials, Young Learners,Needs Analysis

\section{A. INTRODUCTION}

$\mathbf{I}$ $\mathrm{n}$ an informal interview with a school supervisor in Makassar, it was revealed that, the English learning materials for young learners in secondary schools is inappropriate. The inappropriateness was related to the requirement of English learning materials development that it should be based on the 16 principles of second language acquisition proposed by Tomlinson (2011). Therefore, the development of English learners' ability tends to slow down even stagnate.

Based on the experiences before, the researcher had conducted a preliminary study by interviewing some students in third grade of a Junior High School (JHS) in 
Miftahul Khair Nur Ali Mubar, Developing English Learning Materials For Young ...

September 2014 in Makassar. In the preliminary study, it was exposed that the students' needs were not fulfilled by the existing materials. Apart from the problem in learning materials, it was also found that, the students lacked vocabulary and pronunciation.

From the researcher's preliminary study, it was found that, the main source to English learning materials did not exist. The teacher in one class for instance, could only provide the students with a task book compiled from assorted sources. This is one of the many problems encountered by both teacher and students in the learning process. If these problems remain unchanged, the learning objectives stated in curriculum will not be well achieved. In other words, the learning materials set as the source of learning did not macth the content standard of the curriculum.

The materials sometimes hinder the learning process if the media needed to convey the instructional materials are not available. It, of course, becomes a problem in achieving the learning objectives. For example, books as a source of learning materials for students contain the dialogue of listening materials but some of the publishers do not provide listening materials in a compact disc for the buyers, whereas listening materials arevery essential for the students.

Moreover, in some English books, the researcher found that some parts of the materials are designed in deductive models. Deductive model means reasoning from generalizations toward specific examples: the specific facts drawn or inferred from general principles (Brown, 2008). The materials given to students did not guide them to find out by themselves the main points of the learning materials. The researcher assumes that the students should be given inductive models which can guide them to think analitically to materials being learned. It is supported by Brown (2008) that the learning a second language in real life (naturally, without a teacher), as well as learning a first language, involving inductive process, in which the learner must infer certain rules and meaning of the data around them.

Based on the facts stated previously, the researcher assumes that the facts will become a problem if not overcome soon. By doing this research, the researcher expected that this research can solve the problems stated previously by designing English learning materials for young learners focusing on speaking skill. The materials that will be designed by the researcher is supplementary materials because the main materials have been designed by the Ministry of Education and textbooks' publishers. 


\section{B. LITERATURE REVIEW}

Based on the research findings before, the researcher concludes that, the students' need English speaking materials based on their needs to improve their speaking ability. The English teachers should find out the appropriate strategies to increase the students' motivation in learning English and make them enjoy their learning. The developed materials stimulate students to learn because the materials learnt by students are the students want.The researcher develop new materials, it is not only to make students feel at ease in learning English but also can help students to improve their motivation to speak English. So, the target of curriculum is well achieved.

\section{Materials Development}

According to Tomlinson (2001: 66) Materials development is both a field of study and a practical undertaking. As a field, it studies the principles and procedures of the designed, implementation and evaluation of language teaching materials. As a practical undertaking, it refers to anything which is done by writers, teacher or learners to provide source of language input, to exploit those source in ways which maximise the likelihood of intake and to stimulate purposeful output. Materials developers might write textbooks, tell stories, bring advertisements into the classroom, express an opinion, provide samples of language use or read a poem aloud.

\section{English Learning Materials}

Tomlinson (2012) stated that materials is anything which is used to help language learners to learn. Materials can be in the form, for example, of a text book, a workbook, a cassette, a CD-ROM, a video, a photocopied handout, a newspaper, a paragraph written on a whiteboard: anything which presents or informs about the language being learned. The materials can be adopted, developed, or adapted, or some combination of the three (Brown, 1995) but the materials being presented have to consider approaches and syllabuses. Yallden (1987) define syllabus as a "summary of the content to which learners will be exposed".

\section{Young Learners}

The experts at Tufts University, specified four categories of children, they are infants(0-2), early childhood (2-6), child (6-13) and adolescents (13-16). In the otherhand, the Scott and Ytreberg refer to limit the age of 5 to 11 years as young learners (young learners). Slattery and Willis proposed a categorization of two groups: 
Miftahul Khair Nur Ali Mubar, Developing English Learning Materials For Young ...

very young learners $(<7)$ and young learners (>7years). Although the experts are different in classifying young learners age, the researcher state that young learner in this research is students aged 13 to 16 (JHS student).

\section{Needs Analysis}

In general terms, need analysis (also called need assessment) refers to the activities involved in gathering information that will serve as the basis for developing some materials that will meet the learning needs of a particular group of students (Brown, 1995). Needs analysis (in the formal and technical sense) is relatively new in language teaching circles. However, needs analysis have been conducted informally for years by teachers who wanted to asses what language points their students needed to learn.

Richards, Platt, and Weber defined Need analysis as "the process of determining the needs for which a learner or group of learners requires a language and arranging the needs accord.

\section{RESEARCH METHOD}

The research design used by researcher in this research is Research and Development $(\mathrm{R} \& \mathrm{D}) . \mathrm{R} \& \mathrm{D}$ is a name of one research designs involving the classroom problems, studying recent theories of educational product development, developing the educational products, validating the product to experts, and field testing the product (Latif, 2012). The researcher adopts ADDIE Model. ADDIE is acronym of Analysis, Design, Development, Implementation, and Evaluation.

The ADDIE Model is designed to ensure that the learners will achieve the goals and objectives of the learning purposes. It also allows the evaluation of students' needs and provides simple procedure to design and develop materials.

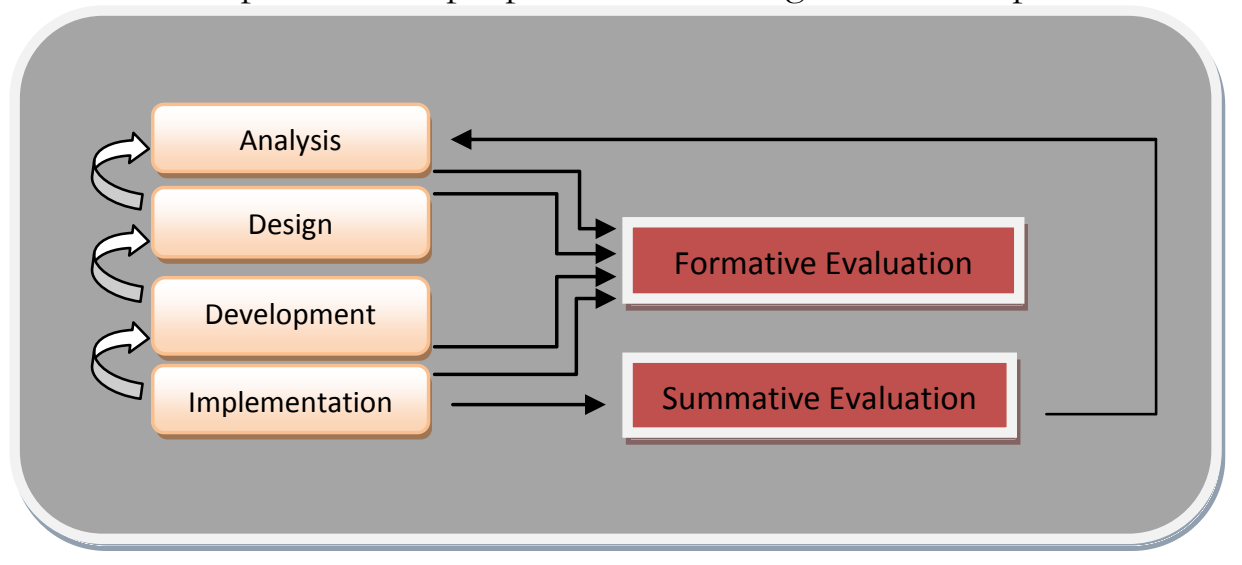

Figure 2. ADDIE Model, Diagram by: Steven J. McGriff 


\section{Research and Development Procedures}

\section{Analysis}

In analysis phase, the researcher indentifies and develops clear understanding of learners' needs. The researcher also identifies a set of goals and objectives of the course based on the existing syllabus used at the school. Then, he considers time line and budget needed in this research. Actually, this phase is similiar to need analysis where need analysis is a set of procedures used to collect information about learners' needs (Richards, 2003:51 as cited in Sukirman 2012).

\section{Design}

This phase, the researcher designs English materials for young learners considering the goals and objectives of the learning process, designing blue print or materials frame work, determining target population description, selecting delivery materials, and identifying as much as sources.

\section{Development}

This phase is done based on the two previous phases, analyze and design phase. There are some steps in doing this phase. First, the reseracher lists what activities which can assist the learners learn the materials. Second, he selects the best way which is appropriate with learners' styles. Third, he develops and produces English for young learners materials dealing with the learners' needs and the goals and objectives of the course. Then, he organizes the materials. After that, he validates the materials to experts to make sure whether the materials is macth to the students' needs as well as the goals and objctives of the course or not. Finally, the final product is ready to be implemented.

\section{Implementation}

This phase deals with trying-out the product. In this case, the product is going to be implemented in the real learning/teaching. Because of this research is undergraduate research so the implementation phase is not done.

\section{Evaluation}

This phase is designed to measure the rate of quality of the materials as being implemented. It measures the content of the developed materials. In this evaluation, one expert is involved to check the quality of the product.

\section{Try-Out Product}

Trying out is done to evaluate whether the materials have fulfilled the learners' needs based on the goals and objectives of the course or not. 
Miftahul Khair Nur Ali Mubar, Developing English Learning Materials For Young ...

\section{Try-out Design}

The try-out design of the study is field try-out. In this case, the product is tried-out to the target subjects in the real learning and teaching situation in order to evaluate the quality of the developed materials. It is beneficial to find out how far the materials fulfill students' needs. Furthermore, in this phase expert and researcher will work together to evaluate the result of field try-out.

\section{Try-out Subjects}

The subject of this research was the third grade students of MTsN Model Makassar who were in. The number of the population was 37 students consisting of 19 boy students and 18 girl students. The distribution of the population can be seen in the following table:

Table 1. The Distribution of the Population

\begin{tabular}{lcc}
\hline Sex Category & $\begin{array}{c}\text { Number of } \\
\text { Students }\end{array}$ & \% \\
\hline Boy & 19 & 51 \\
\hline Girl & 18 & 49 \\
\hline Total & $\mathbf{3 7}$ & $\mathbf{1 0 0}$ \\
\hline
\end{tabular}

From the population above, the researcher selected 20 students as representatives of their friends.

\section{Types of Data}

The types of data obtained in this study is qualitative data. Qualitative data are gathered from the experts' judgement and result of the questionnaire. Expert judgement is comment on developed materials from one of English department lecturer and result of questionnaire is the nineteen questions that answered by the students as need assesment.

\section{Instruments}

This research uses three kinds of instruments. They are rubric, worksheet, and questionnaire. The rubric adapted from Ghobrani (2011:517 - 518) and Wodyatmoko (2011) is used to evaluate or validate the product. The second instrument is worksheet. The worksheet distributed to the expert which including worksheet for expert's comment and suggestion. The third, the questionnaire is given to students for conducting needs analysis.

\section{Data Analyzing Techniques}


In line with the data of this research, there was one way in analyzing obtained data. The data analized qualitatively. The data obtained from the students will be analyzed qualitatively. The data from the expert become attachment and notes for the researcher in developing materials in the form of description of the products, comment, notes, and suggestions.

\section{D.FINDINGS AND DISCUSSIONS}

\section{Third Grade Students' Expectation of Speaking Materials in MTsN Model Makassar}

The students assumed that the majority of speaking materials provided by the teacher to learn in class was difficult and such difficulties were derived from three main sources; materials, socio-psychological factors, and teacher. In terms of materials, some students found it difficult as many difficult words they have to deal with in learning materials. For socio-psychological factors, some students lacked motivation and enthusiasm to learn speaking then these became hindrance for them to learn actively. Teacher as the source of hindrance was more about his/her voice and teaching techniques. For this reason, it is important to think of providing materials with more glossaries in each unit, attractive, and teachable.

For the students, the speaking materials provided by the teacher to learn in class has some strengths according to the students. Some materials have a long term benefit, can be used to practice speaking with friends, and are resourceful for students to achieve a better score in speaking. In some cases, the students also found them good as they could use the materials to practice individually, pair or in group. Some students also responded in terms of teachers' personality and techniques which are considered to be irrelevant with the question.

Beside the strengths, the materials the students learnt also had some weaknesses. Those weaknesses according to the students were more related to their boredom in learning as some materials were found to be monotonous and led to students' boredom. The students also believed that in some materials, it was found to be excessive in grammatical components or a tendency to overuse some English tenses. However, some students also needed more grammatical component but not tenses and they needed more relevant task. Apart from the content, the students also found the materials to be incomprehensible and they needed more translation and more tasks on orthography or spelling cases. One of the student also complained that there was a tendency for the teacher to give them tasks before having fully understand of what to execute. 
Miftahul Khair Nur Ali Mubar, Developing English Learning Materials For Young ...

The number of textbook they have been using so far was only two types but the students felt that both of the textbook had their own strengths and weaknesses. Moreover, using two textbook in learning process indicates that the students didn't have enough source of learning materials to achieve the target of learning objective in curriculum. As the speaking materials should enable students to speak spoken language for their daily life, around $70 \%$ of the students opted that the materials they used in class so far were relevant to their needs.

As the students lacked vocabulary, the students need more vocabulary to present in the beginning of each unit of the speaking materials. They hope, they have activities to enrich their vocabulary.

One way to improve their vocabulary was by looking up the meaning of a word in the dictionary. In this case, they should be taught how to use context. As half of the students admitted that they were used to train themselves pronounce English, they should need a self-access learning more to be used at home.

In terms of colorful textbooks, more than a half student like it. The students assumed that colorful materials will stimulate excitement and interest to materials. In addition, the color of materials should be well arranged because consideration of printing cost.

At the age of young learner, textual book is not interesting. Otherwise, the pictorial textbook will stimulate their sense of curiosity to the materials. More than $70 \%$ of students liked pictorial textbook picture. Based on these facts, the use of pictures in the material must be increased. Furthermore, the pictures that will be usedin thedeveloped materials arepictures of human and cartoon.

As much as $60 \%$ of students liked the deductive materials model. They prefer to be given main topic at the beginning then given examples. Only a few of them who liked inductive materials model. For this reason, the material that will be developed will provide examples for each subject matter and using deductive model. The teacher should provide few examples of the topic being learned.

The improvement in speaking should be one of the many objectives set when students are forced to learn speaking. In such a case, the students found that their achievement improved in terms of fluency, pronunciation, vocabulary, and more important was in broadening their horizon. Along with this, they also felt that their interest and motivation had improved as they endured in learning it. The major difficulties hampered the students in learning to speak are more related to lacking vocabulary and problem with pronunciation.In terms of time allocation in learning speaking, most of the students agreed that it was not enough. 
As for the learning strategies in speaking, most of the students preferred to practice it with friends. The exercise of designed materials should be developed with lots of activities that involve interaction among students.

Half of the respondents agreed that more and more speaking in front of a mirror will improve their speaking ability. Another way that can be used is to join English club to get a supportive environment. As addition, one of students said that learning from good English person is more effective. on the contrary, according to them by talking directly to the native speaker is not best way to improve speaking. by considering this, students may be given homework to record them selves speaking in front of a mirror.

The question number nineteen is answered with a variety by the students. most students expect their ability to speak English improved, especially in terms of speak to Indonesian also English native. They hope, they are good at fluency, pronunciation, accuracy, using grammar, as well as easy in communication using English. Beside that, the other students expected bright future with English. The students want to be a teacher and study abroad.

\section{The Description of Existing Speaking Materials for Third Grade Students of MTsN Model Makassar}

\section{a. The Materials and Students' Needs}

1) Material order

The textbook used inductive materials models. Inductive model means the students are given example and they are asked to conclude and analize what being learned. So far, the textbook well-graded. However, the students need deductive materials order.

Most of students agreed that materials at the beginning than example. For this reason, As the students need more example in every topic, the researcher provide more example for students.

\section{2) Material Content}

All students expected their speaking ability is fluent, good and acceptable. However, students' needs are not fulfilled. It is caused by the textbook only have five activities to improve students' speaking ability. This case experienced by the researcher while sitting in the same class. Until now, He cannot speak English fluently because there is not enough fulfillment of speaking activity during studying in junior and senior high school. So, the researcher develope speaking activities whether mix with another activity or not. 
Miftahul Khair Nur Ali Mubar, Developing English Learning Materials For Young ...

The speaking materials did not provide local culture. In the textbook, there is no local value such as Makassar, Bugis, Toraja and Mandar presented by the publisher. The researcher assumed this is because the textbook printed in Jakarta. The textbook's design is based on national standardization. In fact, the Ministry of Education recognize that one of weakness of textbooks used by students is no local content (Ghozali, 2011). For this reason, the researcher provide materials consist of local content.

The textbook has been used at the appropriate level of difficulty. The materials in the textbook is not moving quickly from one to another. The researcher assumes, this will make the students understand the material being learned. However, there is no glossary that provides vocabulary to help students in understanding uncommon word in the materials. So, the vocabulary box is important for students. Moreover, as the students lacked pronunciation, in every vocabulary boxes there is reminder for the students to pronunce every words correctly.

As the English class runs twice a week, the authors believe that all of activities in the textbook can be finished in one semesters. These activities may also designated to homework. Speaking activities such as the question of what is your fovorite food will last a long time. In addition, play games such as Bingo is also considered to be long-lasting. This is due to the development of every child aged 1516 years tend same. Everyone will feel comfortable when asked about his/her self. Moreover, all ages love game. It is important to adopt the materials.

The presence of group order in the activity allows teachers to control the activities easily. The materials used reflect the use of daily conversation. The learned materials probably used by the students outside classroom. The use of games also illustrates that the material considering what is preferred by students. Moreover, the students need interactive activity in the class. So, the reseacher provide pair and group speaking activity at the developed materials.

The materials presented to the students did not achieve a good balance between four English skills. This is because of speaking, listening, reading, and writing activity not at the portion. The textbook is designed to provide more activities in reading and writing while speaking and listening is very little. Along with this, the reseacher developed more speaking activity than the textbook.

3) Understandble

For the students, the materials presented previously was difficult to understand because of two factors. The first is the word of the materials. Most of students lacked vocabularies. It makes them difficult to understand the materials. So it is important to provide glossary (vocabulary box). 
The second is the teacher. Teacher's voice in delivering materials become problem for students becuase they did not hear what teacher saying. The students hope their teachers good at delivering materials. So, it is very important to be payed attention by the English teachers at the class.

4) Strengths

The strength of the materials are have a long term benefit. For the students, the materials can be used to practice speaking in dily life. The students assumed the materials are good because can be practiced individually, pair or in group. So, the researcher will adopt these materials in developing new speaking materials.

5) Color and Picture

Third grade students are generally aged 15-16 years. For some students in third grade of junior high school, the textbook is interesting. For some others it is not. In the materials, speaking activities not only use text but also using appropriate image of students' age. Pictures stimulate students' knowledge that make them interested and curios. Moreover, based on the students' needs, the use of cartoon and human must be balanced.

It is known that, the use of image is to increase students' knowledge. But, for some students, the textbook design still categorize them into children who are not mature. By reviewing the psychomotor development of children aged 12 to15 years old, some students at the class have started their critical stage of early adolescence. At this age, they have started to refuse and snap. So, as the students need textual and pictorial text, it is important to balance between text and picture.

In term of materials' color, the book uses two colors: black and white. Similar to the use of images/pictures, some students would agree that, the colorful textbook would be interesting to be learnt, while others would not. Textbooks are using two colors by considering the cost of printing that uses only two colors. So, the researcher will develop colorful page and black-white page.

\section{The Description of Developed Speaking Materials for Grade Nine of MTsN Model Makassar}

\section{a. Materials Production}

In developing materials, there are three possible ways of materials application: adopting, writing and adapting (Hutchinson and Waters, 1987:96). The developed materials was adopted from existing materials to bridge the gap between general English to specific technical English and to introduce them more speaking activities. the researcher compile some sources into one unit speaking materials 
Miftahul Khair Nur Ali Mubar, Developing English Learning Materials For Young ...

consist twenty-four activities. The souces are from My English Workbook, English on Sky and Internet. The materials arranged refer to syllabus by the ministry of education and considering students' needs.

\section{b. Framework of the materials}

The developed materials designed by reseracher namely speaking materials for the third grade students. The materials consist of twenty-four activities in twentyfour pages. It provides a clear and coherent unit structure and embodies a view of the nature of language and learning (Hutchinson and Waters, 1987:107).

Here are the appearance of developed materials;
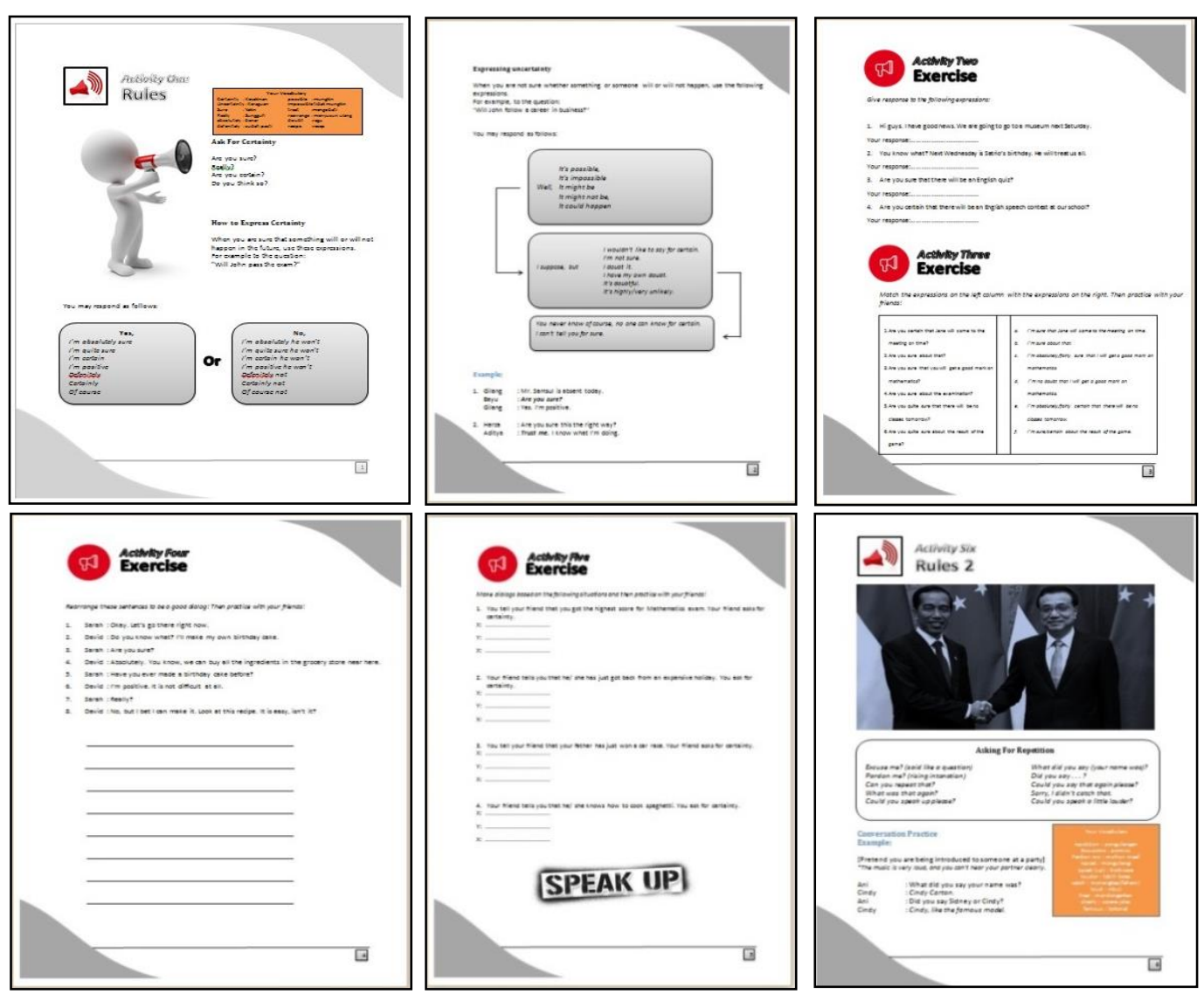
Volume I, Number 02, December 2015
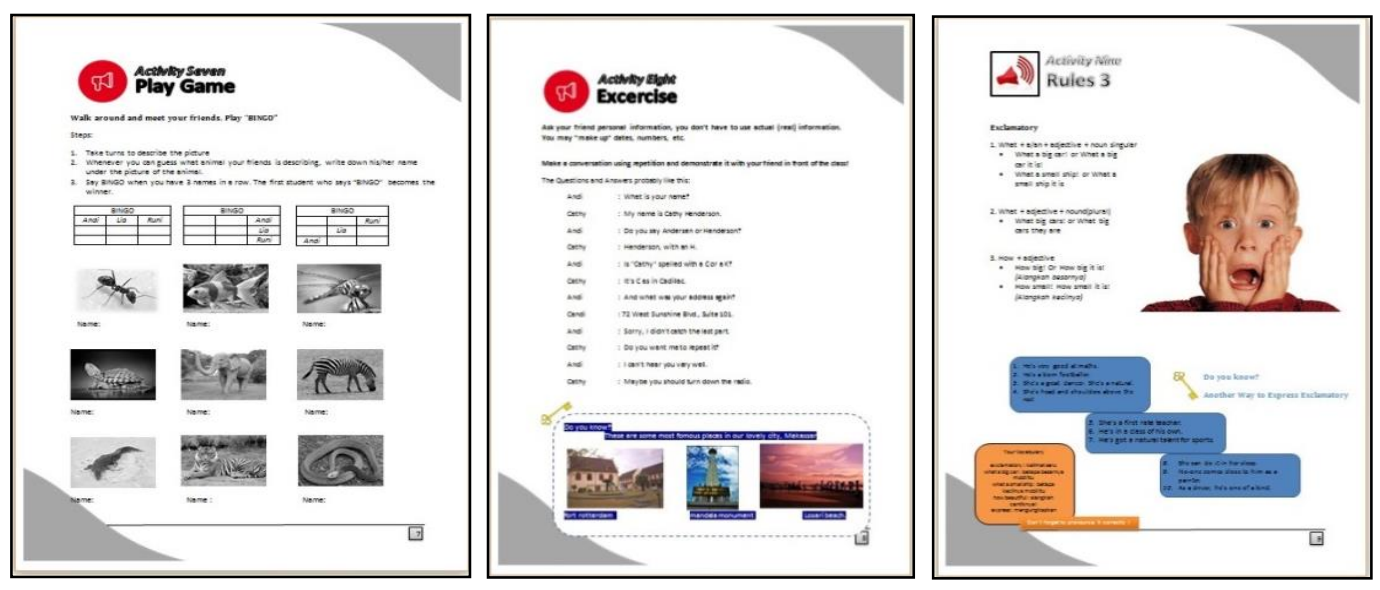
Miftahul Khair Nur Ali Mubar, Developing English Learning Materials For Young ...
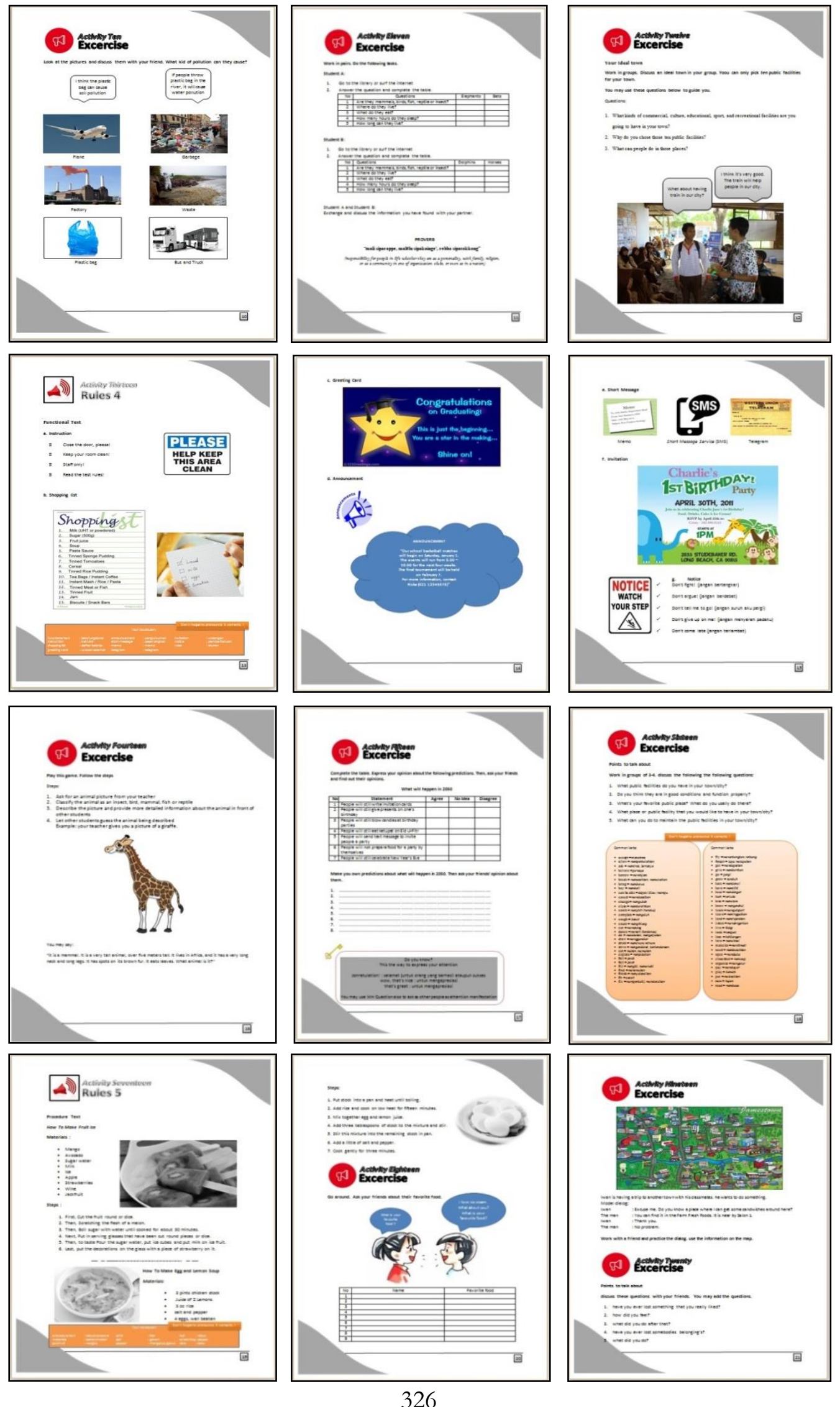

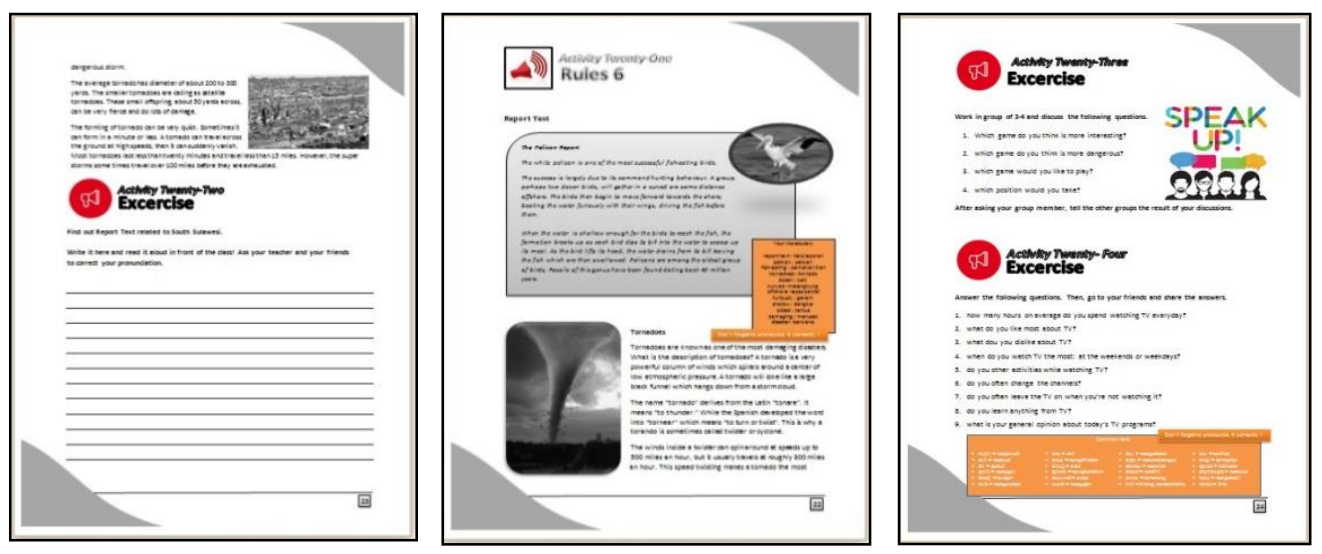

Figure 2. The Appearance of Developed Materials (Full page attached)

\section{The Congruency Level between the Developed Speaking Materials and the Actual Speaking Needs of Grade Nine of MTsN Model Makassar}

The materials in the textbook have four activities; they are reading, writing, listening ands peaking. The four skills are joined together in a variety of activities. Unfortunately, the number of speaking activities for students were not in accordance with the guidance ofthe syllabus based on Ministry of Education rule number 22 in 2006 about KTSP. In fact, from 96 activities, the textbook only provides five speaking activities for students and most activities are writing. In accordance with this finding, the reseacher designed 24 speaking activities based on the syllabus.

In terms of layout, overall, students' text book used two colors: black and white. In terms of using picture, the textbook is good. The picture that used by the textbook is cartoon. The book also use some photos converted to black and white. Because the students want pictorial materials, the needs are fulfilled by colorful pages with many pictures/images using cartoon and human.

The textbook used inductive materials models while the students want deductive models. The book did not have local content to educate/introduce students to their culture and the researchers did not see any vocabulary box(glossary) in the book. The needs are fulfilled by desinging materials in deductive way. The main topic is put in front before examples. For the students who were trouble with vocabulary, the researcher provides vocabulary box in a page with main materials also in the middle and the end of the materials.

The researcher adapts speaking game activity because the existing materials were monotonous. For the over use of grammar, the researcher designs activities that ask the students to speak without trap in grammar. To accomodate students who need more translation, vocabulary boxes can be use as the solution. At last, the 
Miftahul Khair Nur Ali Mubar, Developing English Learning Materials For Young ...

reseacher developed speaking materials by adopting and adapting materials from $\mathrm{My}$ English Woorkbook, English on Sky and internet.

\section{E. CONCLUSION}

Materials development in creating English learning materials especialy speaking materials should be based on goverment rules and students' need. the materials should condsider what students want to achieve better result. When the students needs are fulfilled by presented materials, the researcher believe the taget of learning abojective in syllabus will achieve well.

The students hoped that, their teachers are good in teaching them. The teachers should know how to developed students' English materials. Moreover, the teachers are asked to organize well the learning process and more prepared with lesson plan. The students hope their teachers can teach well and improve their speaking abilty.

The English learning materials for students called speaking materials consist of six rules as main topic and 18 activities to improve students' speaking ability. Thematerials presented in 24 pages. It is presented colorfull with many pitures(images) and presenting local contents for the students. Thematerials developed based on the result of needs assesment and Ministry of Education rule number 22in 2006about KTSP.

English Speaking materials, the materials developed by the researcher was found to be able to accommodate students' needs in learning speaking related to students' daily activity. Moreover, it is suitable to government rules. By adopting and adapting many sources of speaking materials, the materials are believed can improve students' speaking ability.

\section{F. SUGGESTION}

For the students; they are recommended to use any learning materials that best suit their needs in learning. They are also recommended to ask their English teachers what they want in learning. By doing so, they help teachers and goverment in achieving curriculum goals.

For the teacher; it would be better if the teachers conduct needs assesment in the beginning of every semesters. Itis to identify what his/her students actually need. By doing this, the learning process can be more interesting for the students.

For the school (MTsN Model Makassar); it is suggested that the headmaster can support the effort to provide better learning materials for their school. 
Theheadmaster can make an independent team as selector who select all of textbook that will be used at the school. So, the textbook used by the students is good in quality.

For other researchers; developing English learning materials for the students are actually easy. Itis not difficult and very complicated to be done.Theyare suggested to check the learning materials firstly if they want to overcome problems in a class.

\section{REFERENCES}

Brown, H., D. Prinsip Pembelajaran dan Pengajaran Bahasa. Terj. Principles in Learning and Teaching Language. Jakarta: Kedutaan Besar Amerika Serikat, 2008.

Brown, J., D. The Elements of Language Curriculum. Boston: Heinle \& Heinle Publishers, 1995.

Cunningsworth, A. Evaluating and Selecting EFL Teaching Materials. London: Heinemann Educational Books, 1984.

Dubin, F., and Elite O. Developing programs and materials for language learning. New York: Cambridge University Press, 1986.

El-Nimer, G. et al. Technical Report in Oral Presentation. Harlow: Longman, 2008.

Ghozali, I. "Pengembangan Buku Teks Bahasa Inggris Integratif untuk Sekolah Menengah Kejuruan: Penelitian Pengembangan Pendidikan di Sekolah Menengah Kejuruan Usaha Jasa Pariwisata di Jogjakarta”, Thesis, Semarang: Program Pascasarjana, Universitas Sebelas Maret, 2011.

Hutchinson, T., and Waters, A. English for Specific Purposes: A learning-Centered Approach. Cambridge: Cambridge University Press, 1987.

Idrus, N., H. "Designing Learning Materials to Develop Oral Presentation Skills of The Students in Stikes Sandi Karsa Makassar", Thesis, Makassar: Program Sarjana, UIN Alauddin Makassar, 2009.

Jacobson, E., Degener, S., and Purcell-Gates, V. Creating Authentic Materials for the Adult Literacy Classroom: A Handbook for Practitioners. Cambridge, MA: World Education, Inc., 2005.

Latif, M. A. Research Methods on Language Learning (An Intriduction). Malang: UM Press, 2012.

Mukarto et. al. English on Sky. Jakarta: Penerbit Erlangga, 2004.

Muller, T. "Implementing TBL with Learners of Various Ages". In Edwards, C. and Willis, J. (Eds.). Teachers Exploring Tasks in English Language Teaching. London: Palgrave Mc. Millan, 2005. 
Miftahul Khair Nur Ali Mubar, Developing English Learning Materials For Young ...

Nation, I. S. P. and Jonathan N. Teaching ESL/EFL Listening and Speaking. New York: Routledge Press, 2009.

Sujatmiko et. al. My English Workbook. Jakarta: Penerbit Erlangga, 2008.

Sukirman."Developing English Morphology Course Materials for Undergraduate Student at State Islamic University of Alauddin Makassar", Thesis, Malang: School of Graduate Studies, Malang State University, 2012.

Tomlinson, B. Materials Development in Language Teaching. United Kingdom: Cambridge University Press, 2011.

Williams, D. "Developing criteria for textbook evaluation”, An Article. ELT Journal, 37(3), pp. 251-255, 1983.

Yalden, J. The Communicative Syllabus: Evolution, Design and Implementation. Englewood Cliffs N.J.: Prentice Hall International, 1987.

"Certainty and Uncertainty". http://www.myenglishpages.com/site_php_files/ commun ication -lesson-certainty-uncertainty.php\#.VOaRQuF33Hw (March $\underline{132015)}$

“Admiration”.http:/ / findbelow.blogspot.com/2013/06/expressing-admirationmengungk apkan. html (March 132015$)$

“Ask for Certainty". http://estijatenglishlesson.blogspot.com/2011/07/ask-for-andexpress -certainty.html_(March 13 2015)

“Asking Repetition”. http://www.eslgold.com/speaking/asking_repetition.html (March 132015)

"Buginese Proverb". http://hasyimsoppeng.blogspot.com/2013/03/buginesesproverbs. html (March 13 2015)

“Common Verb”. http://www.englishindo.com/2011/11/100-kata-kerja-palingterkenal. html_March 13 2015)

"Computer Generated Image". Wikipedia. http://en.wikipedia.org/wiki/Computer -generated imagery. (December 11 2014).

“Exclamatory Sentences". http://www.nenadmohamed.com/2008/07/exlamatorysentenc es-alangkah-atau.html (March 132015$)$

"Functional Text". http://haqyjoon.blogspot.com/_(March 13 2015)

"Procedure Text". http://fujianto21-chikafe.blogspot.com/2013/10/5-contohsingkat-procedure-text-pendek.html (March 132015$)$

“Report Text”. http://www.belajarbahasainggris.us/2014/01/penjelasan-reporttext-contoh -lengkap.html_(March 13 2015) 